\title{
Effectiveness of surgery and individualized high-dose hyperfractionated accelerated radiotherapy on survival in clinical stage I non-small cell lung cancer. A propensity score matched analysis
}

Citation for published version (APA):

Jimenez, M. F., van Baardwijk, A., Aerts, H. J. W. L., De Ruysscher, D., Novoa, N. M., Varela, G., \& Lambin, P. (2010). Effectiveness of surgery and individualized high-dose hyperfractionated accelerated radiotherapy on survival in clinical stage I non-small cell lung cancer. A propensity score matched analysis. Radiotherapy and Oncology, 97(3), 413-417. https://doi.org/10.1016/j.radonc.2010.08.016

Document status and date:

Published: 01/12/2010

DOI:

10.1016/j.radonc.2010.08.016

Document Version:

Publisher's PDF, also known as Version of record

\section{Document license:}

Taverne

\section{Please check the document version of this publication:}

- A submitted manuscript is the version of the article upon submission and before peer-review. There can be important differences between the submitted version and the official published version of record. People interested in the research are advised to contact the author for the final version of the publication, or visit the $\mathrm{DOI}$ to the publisher's website.

- The final author version and the galley proof are versions of the publication after peer review.

- The final published version features the final layout of the paper including the volume, issue and page numbers.

Link to publication

\footnotetext{
General rights rights.

- You may freely distribute the URL identifying the publication in the public portal. please follow below link for the End User Agreement:

www.umlib.nl/taverne-license

Take down policy

If you believe that this document breaches copyright please contact us at:

repository@maastrichtuniversity.nl

providing details and we will investigate your claim.
}

Copyright and moral rights for the publications made accessible in the public portal are retained by the authors and/or other copyright owners and it is a condition of accessing publications that users recognise and abide by the legal requirements associated with these

- Users may download and print one copy of any publication from the public portal for the purpose of private study or research.

- You may not further distribute the material or use it for any profit-making activity or commercial gain

If the publication is distributed under the terms of Article 25fa of the Dutch Copyright Act, indicated by the "Taverne" license above,

Download date: 26 Apr. 2023 
Lung cancer radiotherapy

\title{
Effectiveness of surgery and individualized high-dose hyperfractionated accelerated radiotherapy on survival in clinical stage I non-small cell lung cancer. A propensity score matched analysis
}

\author{
Marcelo F. Jimenez ${ }^{\mathrm{a}, *}$, Angela van Baardwijk ${ }^{\mathrm{b}}$, Hugo J.W.L. Aerts ${ }^{\mathrm{b}}$, Dirk De Ruysscher ${ }^{\mathrm{b}}$, Nuria M. Novoa ${ }^{\mathrm{a}}$, \\ Gonzalo Varela ${ }^{\mathrm{a}}$, Philippe Lambin ${ }^{\mathrm{b}}$

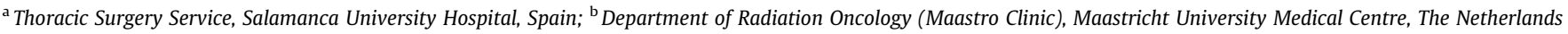

\section{A R T I C L E I N F O}

\section{Article history:}

Received 27 April 2010

Received in revised form 16 August 2010

Accepted 22 August 2010

Available online 28 September 2010

\section{Keywords:}

Non-small cell lung cancer

Lung resection

High-dose radiotherapy

Propensity scoring analysis

\begin{abstract}
A B S T R A C T
Background and purpose: Surgery is considered the treatment of choice for early-stage non-small cell lung cancer (NSCLC). Patients with poor pulmonary function or other comorbidities are treated with radiotherapy. The objective of this investigation is to compare the 3-year survival of two early-stage NSCLC populations treated in two different hospitals, either by surgical resection (lobectomy) or by individualized high-dose accelerated radiotherapy, after matching patients by propensity scoring analysis.

Methods: A retrospective comparative study has been performed on two series of consecutive patients with cytohistological diagnosis of NSCLC, clinically staged IA by means of PET-scan (radiotherapy group) and pathologically staged IA (surgery group).

Results: A total of 157 cases were initially selected for the analysis ( 110 operated and 47 treated by radiotherapy). Patients in the radiotherapy group were older, with higher comorbidity and lower FEV1\% with 3-years probability of survival for operated patients higher than that found for patients treated by radiotherapy. After matching by propensity scoring (using age and FEV1\%), differences disappear and 3-years probability of survival had no statistical differences.

Conclusions: Although this is a non-randomized retrospective analysis, we have not found 3-years survival differences after matching cases between surgery and radiotherapy. Nevertheless, data presented here support the continuous investigation for non-surgical alternatives in this disease.
\end{abstract}

(c) 2010 Elsevier Ireland Ltd. All rights reserved. Radiotherapy and Oncology 97 (2010) 413-417
Surgery, within some subsets followed by chemotherapy, is considered the treatment of choice for early-stage non-small cell lung cancer (NSCLC) [1]. Patients with poor pulmonary function, which is the most frequent comorbidity due to the association between COPD and lung cancer [2], and/or other comorbidities are treated with radiotherapy. As a consequence of this case selection bias, patient's outcomes after radiation therapy are not directly comparable to the ones after surgery.

The objective of this investigation is to compare the 3-year survival of two early-stage NSCLC populations treated in two different hospitals, either by surgical resection (lobectomy) at Salamanca University Hospital by individualized high-dose accelerated radiotherapy at Maastro Clinic, after matching patients by propensity scoring analysis.

\footnotetext{
* Corresponding author. Address: Thoracic Surgery, Salamanca University Hospital, Paseo de San Vicente 58, 37007 Salamanca, Spain.

E-mail address: mfjl@usal.es (M.F. Jimenez).
}

\section{Patients and methods}

Design

This is a retrospective comparative study on prospectively recorded data, after matching cases by propensity scoring analysis.

\section{Study population}

The series of surgically treated cases has been taken from all consecutive cases operated by lobectomy at the Thoracic Surgery Service of the Salamanca University Hospital between January 1994 and April 2007. Selection criteria for inclusion in the analysis consisted of preoperative diagnosis of NSCLC and pathological staging of T1N0M0. Therefore, no patients with induction therapy (radio and/or chemotherapy) were included in this series.

Radiotherapy patients with medically inoperable pathologyproven clinical staging T1N0M0 and T2N0M0 were treated at MAASTRO clinic in the period from September 2005 until April 2007. Patients had not received prior thoracic radiation or chemotherapy. All the patients had to have a moderate to good lung 
function (a forced expiratory volume in $1 \mathrm{~s}\left(\mathrm{FEV}_{1}\right) \geqslant 30 \%$ of predicted value and a carbon monoxide diffusing capacity $($ DLCO $) \geqslant 30 \%$.

Both in surgical and radiotherapy cases, all studied variables and outcomes were defined and recorded prospectively on a customised computerized database. At the time of gathering data for this report, two investigators (GV and AvB) reviewed both databases for inconsistencies and updating survival data.

Informed consent with regard to treatment was obtained from all the patients in both the centres.

Preoperative staging work-up, functional evaluation criteria and perioperative management in surgical series of cases

Perioperative management was uniform for all cases along the study period and it has been previously described in detail [3]. Shortly, cases were selected for surgical therapy if no major comorbidity encompassing a worse prognosis than lung cancer was found, and predicted postoperative FEV1 (ppoFEV1) was over 30\% of its theoretical value for sex, age and height. DLCO was routinely measured starting January 2007. Up to that date, it was indicated only in patients with a ppoFEV $1<40 \%$ or findings of interstitial lung disease at CT scan.

Clinical staging work-up for all the surgical patients was performed by a thorough interview with the patient and clinical examination, bronchoscopy and full-body CT scan. In patients with mediastinal lymph nodes of $1 \mathrm{~cm}$ of diameter or larger, mediastinoscopy was indicated. Starting January 2003, PET scan was performed in patients with enlarged mediastinal lymph nodes and invasive mediastinal staging was indicated if FDG uptake was suggestive of mediastinal lymph node metastases.

At surgery, all the patients were approached by a posterior muscle-sparing or a small axillary thoracotomy, at surgeon's choice. All the cases were operated on by or under supervision of a scrubbed senior thoracic surgeon and a lobectomy with systematic lymph node dissection was always performed.

\section{Radiotherapy treatment}

Radiotherapy patients with medically inoperable cytohistology proven clinical stage I NSCLC (T1NOMO and T2NOM0) were treated at MAASTRO clinic in the period from September 2005 until April 2007. Eligibility for this therapy included only patients who had not received prior thoracic radiation or chemotherapy.

A treatment-planning PET-CT scan was performed with intravenous contrast if the kidney function allowed, before start of radiation on a PET-CT-simulator (Biograph; SOMATOM Sensation 16 with an ECAT ACCEL PET scanner, Siemens).

Delineation was based on fused PET-CT images and performed by the Radiation Oncologist using a standard clinical delineation protocol [5]. The Gross Tumor Volume (GTV) consisted of the primary tumor, which is the CT-based volume. No elective hilar or mediastinal irradiation was carried out. The Clinical Target Volume (CTV) was defined as the GTV with a margin of $5 \mathrm{~mm}$, whereas another $10 \mathrm{~mm}$ margin was added for the Planning Target Volume (PTV). For the calculation of the mean lung dose (MLD), the volume of both lungs minus the GTV was considered [6].

A 3D conformal treatment plan was calculated (XiO, Computer Medical System, Inc.) according to the International Commission on Radiation Units and Measurements guidelines [7] using a Fast Fourier Transform convolution algorithm for inhomogeneity corrections. Patients were irradiated on a linear accelerator (Elekta SL 15, Elekta, Crawley, UK or Siemens Oncor, Siemens Medical Solutions, Concord, CA). Treatment verification was performed using Electronic Portal Imaging Device measurements [8].
An individualized dose-escalation scheme was used for all the patients, as described earlier by our group $[5,10]$. For all the patients the radiation dose was individually escalated until a doselimiting normal tissue constraint was reached: a maximal mean lung dose (MLD) of $19.0 \pm 1.0$ Gray (Gy), a maximal dose for the spinal cord of $54.0 \pm 0.5 \mathrm{~Gy}$, maximal dose to the great vessels or main bronchi of $70.2 \mathrm{~Gy}$ and for the plexus brachialis of $66 \mathrm{~Gy}$ was applied [9]. No specific esophageal dose constraint was used, as acute esophagitis was not considered to be dose-limiting with radiation alone $[5,10]$. The maximal allowed Total Tumor Dose (TTD) was $79.2 \mathrm{~Gy}$ in twice daily (BID) fractions of $1.8 \mathrm{~Gy}$ with an interfraction interval of at least 8-h as described earlier [11]. During radiation treatment, patients were seen weekly by the Radiation Oncologist to treat the radiation-related complaints.

\section{Endpoints}

Survival status of the patients (alive or dead by any cause) was evaluated in July 2009 in both series of cases. In the surgical group, follow-up visits were done at the patient's closest Pulmonology or Oncology department and periodical phone calls from the Thoracic Surgery Department to the patient, relatives or family physician served to inform them on the patient's health status. In the radiotherapy patients, follow-up was done by the Pulmonologist and/or Radiation Oncologist according to the national guidelines [4]. Furthermore, survival was updated using the "Gemeentelijke Basis Administratie" system, a decentralized population registration system containing information about all inhabitants of The Netherlands.

\section{Data analysis}

After normality tests, continuous variables in both series of cases: age, FEV1\%, BMI and Charlson comorbidity index [12] were compared either by Student T-test or by Wilcoxon rank-sum test.

Patient selection bias was addressed by constructing propensity scores $[13,14]$ in order to match patients who were treated by surgery and those who were treated by radiotherapy. Before matching patients, logistic regression model was developed (using bootstrap resampling technique) to evaluate the clinical variables related to the type of treatment. The variables used in the model were: age, clinical T-status, FEV1\% and Charlson Comorbidity Index. All variables were known for all patients.

Variables related to the type of treatment with a $p<0.05$ at logistic regression analysis were used in the matching process. Pairs of comparable cases were created using propensity-scoring algorithms (matching method was 1:1 nearest neighbour, without replacement).

Survival of the patients was evaluated by Kaplan-Meier estimation and the survivor functions of the different groups of cases were compared by the log-rank test. Also the incidence rate ratios and its 95\% CI limits for both types of therapy were calculated. Survival analysis was performed twice. First, all the cases were considered and then, only matched pairs of cases treated either by surgery or radiotherapy were analysed. Thirty-day mortality of both series of cases was included in the survival analysis. All calculations and graphics were performed using Stata 11.0 (StataCorp, Texas, USA) after implementing the user-written psmatch2 module.

\section{Results}

A total of 157 consecutive cases of stage I were initially selected for the analysis (110 operated and 47 treated by radiotherapy). Demographics, clinical characteristics and treatment characters of both series of cases can be found in Table 1. Patients in the radiotherapy group were older $(p=0.02)$, with higher Charlson's comorbidity index $(p=0.0002)$ and lower FEV1\% $(p<0.0001)$. No 
Table 1

Demographics, clinical characteristics and treatment characters of both series of cases.

\begin{tabular}{llll}
\hline & Radiotherapy & Surgery & $\begin{array}{l}p \\
\text { Values }\end{array}$ \\
\hline Nr. of cases & 47 & 110 & - \\
Female/male & $11 / 36$ & $11 / 99$ & - \\
cT1/T2 & $28 / 19$ & $110 / 0$ & - \\
Age (mean, S.D.) & $68.5(10.5)$ & $64.5(9.4)$ & 0.025 \\
Charlson index (mean, S.D.) & $2.4(1.3)$ & $1.5(1.1)$ & 0.0002 \\
FEV1\% (mean, S.D.) & $53.9(17)$ & $86.2(22.2)$ & $<0.0001$ \\
Median radiotherapy dose & $79.2 \mathrm{~Gy}$ & $\mathrm{NA}$ & \\
$\quad$ prescribed (range) & $(50.4-79.2 \mathrm{~Gy})$ & & \\
$\begin{array}{c}\text { Percentage of patients receiving } \\
\text { the prescribed dose }\end{array}$ & $95.7 \%(45 / 47)$ & $\mathrm{NA}$ & \\
\hline
\end{tabular}

differences were found between groups about the histology type. 30-day mortality was $1.9 \%$ (2 cases) after lobectomy and $2.1 \%$ (1 case) after completion of radiotherapy treatment.

Comparing the survival of the total group of patients, 36 month probability of survival for operated patients was 0.78 (95\%CI: $0.67-$ 0.85 ) higher than that found for the patients treated by radiotherapy 0.44 (95\%CI: $0.28-0.58) \log$-rank $p=0.0004$. The incidence rate ratio was 2.57 ( $95 \% \mathrm{CI}: 1.54-4.29, p=0.002$ ). On logistic regression analysis, age, clinical T-status and FEV1\% were related to the type of treatment ( $p<0.001$, all variables) and were used to calculate propensity scoring indexes, while Charlson's comorbidity score was only marginally related $(p=0.06)$. After matching by propensity scoring, 28 pairs of cases were available for survival analysis.
In this subset of matched cases, the differences of age disappeared. Mean age was 68 (S.D. 1.52) in the surgical group and 68.6 (S.D: $1.64)$ in the group of cases treated by radiotherapy $(p=0.79)$. FEV1\% was still lower in the radiotherapy group (mean 51.9; S.D. 3.37 vs mean 62.4 , S.D. 2 in the surgical subset; $p=0.01$ ) but differences decreased when compared to the values found in the series before matching cases. Comparison of age and FEV1\% between surgery and radiotherapy series before and after propensity score matching are presented in Fig. 1.

After the matching process, 36-month probability of survival was 0.73 (95\%Cl: $0.49-0.87$ ) for the operated cases and 0.56 (95\%CI: 0.33-0-73) for the radiated subset of patients; with no statistical differences after log-rank test $(p=0.56)$. The incidence rate ratio for the matched patients was 0.99 (95\%CI: 0.41-2.37; $p=0.50)$.

Survival curves for both the entire populations and for the matched cases are presented in Fig. 2A and B, respectively.

\section{Discussion}

In the absence of randomized clinical trials, lobectomy with mediastinal lymph node dissection is considered the treatment of choice in early-stage NSCLC [1]. Recent technical developments, such as video-assisted procedures [15], and improvements in perioperative care have decreased surgical mortality and nowadays 30 -day mortality after lobectomy is expected to be around $2 \%$ [16]. We found similar results in our series with treatment-related mortality between $1.9 \%$ for lobectomy and $2.1 \%$ for radiotherapy. Unfortunately, the majority of newly diagnosed NSCLC cases
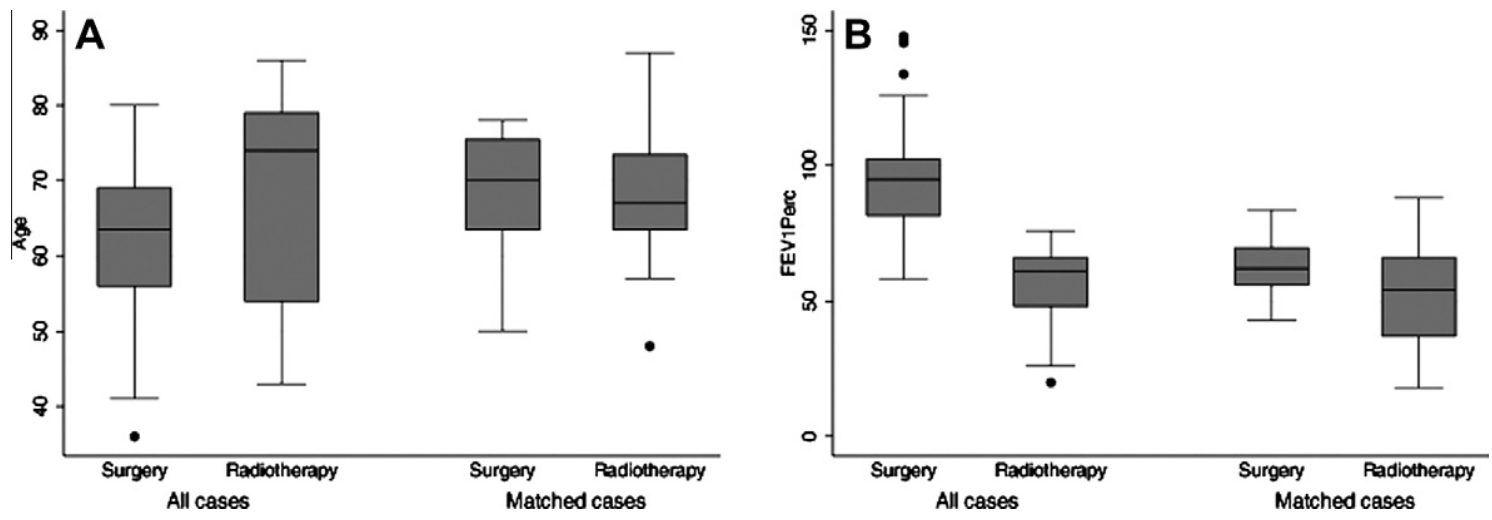

Fig. 1. Comparison of age (A) and FEV1\% (B) between surgery and radiotherapy series of cases before and after propensity score matching of the patients.
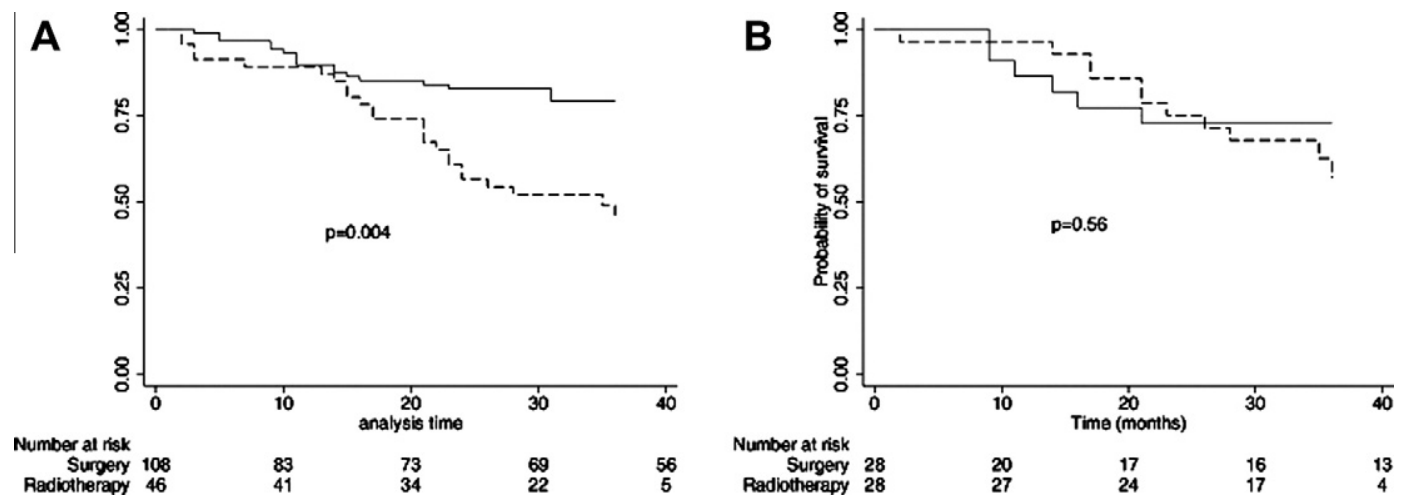

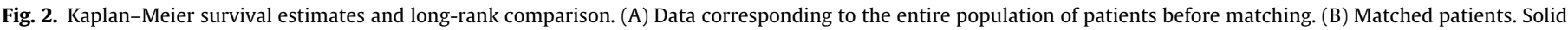
lines represent surgically treated patients in both figures. 
cannot be operated on due to the local or distant spread [17] or patient's comorbidity.

Concerning effectiveness of surgical therapy, the IASLC Lung Cancer Staging Project [18] reported 5-year survival rates of $77 \%$ and $71 \%$, after radical excision of pT1N0 tumors of $2 \mathrm{~cm}$ or smaller (pT1a; $n=1816$ patients) and tumors between 2 and $3 \mathrm{~cm}$, respectively (pT1b; $n=1653$ patients). Corresponding 5-year survival rates for pathologically staged T2NO tumors measuring $3-5 \mathrm{~cm}$ (pT2a; $n=2822), 5-7 \mathrm{~cm}$ (pT2b; $n=825)$, and greater than $7 \mathrm{~cm}$ (pT2c; $n=364$ ) were $58 \%, 49 \%$, and $35 \%$, respectively ( $p<0.0001$ ). When examining survival rates according to clinical stage instead of pathological stage, the 5-year survival rates were as low as $53 \%$ for T1a and $26 \%$ for T2c tumors.

Several surgical techniques, anatomical or wedge segmentectomy have been proposed as an alternative to lobectomy for the treatment of T1 and small T2 tumors with apparently favourable results [19] but their convenience has been debated due to the evidence of lung volume reduction effect of lobectomy in emphysema patients [20,21].

Conventional radiation therapy was the preferred treatment in patients with stage I NSCLC who were unfit to undergo surgery or who declined surgery. This is, however, a less attractive alternative to surgery in operable patients as the mean-reported crude local recurrence rates are as high as $70 \%$, resulting in a three year overall and cause-specific survival of only 34\% and 39\%, respectively [22]. Conventional radiotherapy involves daily treatment sessions over a 5-7 week period, and inadequate local tumor control is mainly the result of insufficiently high-doses, and target miss caused by tumor mobility [23].

Several techniques have been introduced to improve the outcome in radiotherapy for NSCLC, including dose-escalation and accelerated radiotherapy to overcome repopulation. In a systematic review of the literature [24], the authors found 26 non-randomised studies reporting 3-year cancer-specific survival ranging from $22 \%$ to $56 \%$, they concluded that better outcomes are seen in patients with T1 tumors treated by continuous hyperfractionated accelerated radiotherapy (CHART) or conventionally fractionated doses of $60 \mathrm{~Gy}$ or more. More recently, phase II studies on stereotactic radiotherapy (SRT) have shown 3-year cancer-specific survival ranging $72-88 \%$, while overall survival was worse in the series due to a high mortality rate as a consequence of associated diseases [25-29]. The study by Onishi et al. [30] is a multi-institutional retrospective analysis. The authors included in their review nearly 100 patients who were deemed operable but refused surgery. In this subset, the 5-year overall survival rate observed after a biologically effective dose of $100 \mathrm{~Gy}$ was $70.8 \%$, equivalent to the outcome after surgery.

The literature comparing the effectiveness of radiotherapy and surgery is scanty and usually biased since patients treated by radiotherapy are considered medically non-operable [24] or refused surgical treatment. Recently Grills et al. [31] published a study in a cohort of stage I patients ineligible for anatomical lobectomy, they found no differences in loco regional recurrence or cause-specific survival between SRT and wedge resection.

In this report, we have evaluated long term survival of two comparable series of patients receiving surgery or individualized highdose hyperfractionated accelerated radiotherapy. All radiotherapy patients underwent a plannings PET-CT scan, since PET-CT might improve the delineation of the GTV and in selected cases allows dose-escalation $[32,33]$. All surgery patients were p-NO after lymphadenectomy. For calculating the propensity score indexes we used only variables related to the treatment type in logistic regression analysis: age, stage I-A and FEV1\%.

The applied schedule combines a short overall treatment time in order to decrease the effect of accelerated proliferation of tumor cells, which typically occurs at about 4 weeks of radiotherapy, with a high radiation dose that is tailored to a predicted probability of pneumonitis. This schedule allows the delivery of very high biological doses to the tumor with a low incidence of side effects [11]. For example, the biological equivalent of the classical $60 \mathrm{~Gy}$ delivered in 30 fractions in 6 weeks is only about $48 \mathrm{~Gy}$, while the $79.2 \mathrm{~Gy}$ in 44 fractions in 4.5 weeks as used in this series, is equivalent to $71 \mathrm{~Gy}$, or otherwise said, the presently delivered $79.2 \mathrm{~Gy}$ in 4.4 weeks is the same for the tumor as approximately $100 \mathrm{~Gy}$ given in 50 fractions in 10 weeks, but with the same toxicity to the normal tissues as $79 \mathrm{~Gy}$. The biological equivalent of the fractionation regimen used in this series comes close to doses as used in stereotactic body radiation series, but can also be used in centrally located tumors.

The relatively small number of cases treated by radiotherapy is one of the limitations of this study. Besides we have to acknowledge several limitations in our study. The first one is the different criteria followed to select patients for surgery in both the centres since some of the cases from each group could have been treated in a different way if he would have been evaluated in the other centre. Due to the characteristics of the study we cannot control this limitation. The type of protocol for clinical staging was also different. While all the cases in the radiotherapy group underwent PET-CT for staging and treatment planning, only a minority of cases in the surgical group were staged by PET. According to this, the accuracy of the clinical mediastinal staging in the surgical group was lower and some cases could have been misclassified in stage IA, but all the patients underwent a lynphadenectomy and were pathological NO. Moreover the lack of preoperative surgical staging in the radiotherapy group is also an important limitation of our study but as a recent paper points out among operable and even marginal patients surgical or endobronquial ultrasonography staging is essential both for prognosis and for treatment planning [34].

As we have commented before, overall survival is lower than cancer-related in the published series of cases treated by radiotherapy. In our investigation, death due to any cause was the selected end point. This seems to be reasonable due to the fact that it is a retrospective analysis in different types of cases included in each group and the different follow-up protocols.

We cannot conclude from our data that both the studied therapies have comparable effectiveness in the treatment of clinical stage I NSCLC because the number of cases is not enough and some systematic non-controllable bias could have affected our investigation. Nevertheless, data presented here support the continuous investigation for non-surgical alternatives in this disease, as the two phase III trials that are ongoing, comparing SRT with surgery for patients with stage I lung cancer: the Randomized Clinical Trial of Either Surgery or Stereotactic Radiotherapy for Early Stage (IA) Lung Cancer (ROSEL) trial in the Netherlands [35] and the Accuray Cyberknife worldwide trial [36], or to explore the cost-effectiveness, the best current treatments for NSCLC and the value of additional research [37].

\section{Conflict of interest statement}

All authors declare no conflict of interest regarding our article.

\section{References}

[1] Wright G, Manser RL, Byrnes G, Hart D, Campbell DA. Surgery for non-small cell lung cancer: systematic review and meta-analysis of randomised controlled trials. Thorax 2006;61:597-603.

[2] Wasswa-Kintu S, Gan WQ Man SFP, Pare PD. Relationship between reduced forced expiratory volume in one second and the risk of lung cancer: a systematic review and meta-analysis. Thorax 2005;60:570-5.

[3] Novoa N, Varela G, Jimenez MF. Morbidity after surgery for non-small cell lung carcinoma is not related to neoadjuvant chemotherapy. Eur J Cardiothorac Surg 2001;20:700-4.

[4] Landelijke Werkgroep Longtumoren. Niet-kleincellig longcarcinoom, landelijke richtlijn (version 1.3). VIKC; 2004. 
[5] van Baardwijk A, Bosmans G, Boersma L, et al. Individualized radical radiotherapy of non-small-cell lung cancer based on normal tissue dose constraints: a feasibility study. Int J Radiat Oncol Biol Phys 2008;71:1394-401.

[6] Senan S, De Ruysscher D, Giraud P, et al. Literature-based recommendations for treatment planning and execution in high-dose radiotherapy for lung cancer. Radiother Oncol 2004;71:139-46.

[7] ICRU. International commission on radiation units and measurements report 50: prescribing, recording, and reporting photon beam therapy; 1993.

[8] Nijsten SM, Mijnheer BJ, Dekker AL, et al. Routine individualised patient dosimetry using electronic portal imaging devices. Radiother Oncol 2007;83:65-75.

[9] Fowler JF, Bentzen SM, Bond SJ, et al. Clinical radiation doses for spinal cord: the 1998 international questionnaire. Radiother Oncol 2000;55:295-300.

[10] Belderbos J, Heemsbergen W, Hoogeman M, et al. Acute esophageal toxicity in non-small cell lung cancer patients after high dose conformal radiotherapy. Radiother Oncol 2005;75:157-64.

[11] van Baardwijk A, Wanders S, Boersma L, et al. Mature results of an individualized radiation dose prescription study based on normal tissue dose constraints in stages I to III non-small-cell lung cancer. J Clin Oncol 2010;28:1380-6.

[12] Birim O, Maat APWM, Kappetein AP, et al. Validation of the Charlson comorbidity index in patients with operated primary non-small cell lung cancer. Eur J Cardiothorac Surg 2003;23:30-4.

[13] Dehejia RH, Wahba S. Propensity score-matching methods for nonexperimental causal studies. Rev Econ Stat 2002;84:151-61.

[14] Blackstone EH. Comparing apples and oranges. J Thorac Cardiovasc Surg 2002;123:8-15.

[15] Farjah F, Wood DE, Mulligan MS, et al. Safety and efficacy of video-assisted versus conventional lung resection for lung cancer. J Thorac Cardiovasc Surg 2009;137:1415-21.

[16] Brunelli A, Varela G, Van Schil P, et al. Multicentric analysis of performance after major lung resections by using the European Society Objective Score (ESOS). Eur J Cardiothorac Surg 2008;33:282-8.

[17] Little AG, Gay EG, Gaspar LE, et al. National survey of non-small cell lung cancer in the United States: epidemiology, pathology and patterns of care. Lung Cancer 2007;57:253-60.

[18] Rami-Porta R, Ball D, Crowley J, et al. The IASLC Lung Cancer Staging Project: proposals for the revision of the $\mathrm{T}$ descriptors in the forthcoming (seventh) edition of the TNM classification for lung cancer. J Thorac Oncol 2007;2:593-602.

[19] Rami-Porta R, Tsuboi M. Sublobar resection for lung cancer. Eur Respir J 2009;33:426-35.

[20] Varela G, Brunelli A, Rocco G, et al. Evidence of lower alteration of expiratory volume in patients with airflow limitation in the immediate period after lobectomy. Ann Thorac Surg 2007;84:417-22.

[21] Sekine Y, Iwata T, Chiyo M, et al. Minimal alteration of pulmonary function after lobectomy in lung cancer patients with chronic obstructive pulmonary disease. Ann Thorac Surg 2003;76:356-61.

[22] Qiao X, Tullgren O, Lax I, et al. The role of radiotherapy in treatment of stage I non-small cell lung cancer. Lung Cancer 2003;41:1-11.
[23] Mehta M, Scrimger R, Mackie R, et al. A new approach to dose escalation in non-small-cell lung cancer. Int J Radiat Oncol Biol Phys 2001;49:23-33.

[24] Rowell NP, Williams CJ. Radical radiotherapy for stage I/II non-small cell lung cancer in patients not sufficiently fit for or declining surgery (medically inoperable): a systematic review. Thorax 2001;56:628-38.

[25] Zimmermann FB, Geinitz H, Schill S, et al. Stereotactic hypofractionated radiotherapy in stage I (T1-2 NO MO) non-small-cell lung cancer (NSCLC). Acta Oncol 2006;45:796-801.

[26] Koto M, Takai Y, Ogawa Y, et al. A phase II study on stereotactic body radiotherapy for stage I non-small cell lung cancer. Radiother Oncol 2007;85:429-34.

[27] Fakiris AJ, McGarry RC, Yiannoutsos CT, et al. Stereotactic body radiation therapy for early-stage non-small-cell lung carcinoma: four-year results of a prospective phase II study. Int J Radiat Oncol Biol Phys 2009;75:677-82.

[28] Baumann P, Nyman J, Hoyer M, et al. Outcome in a prospective phase II trial of medically inoperable stage I non-small-cell lung cancer patients treated with stereotactic body radiotherapy. J Clin Oncol 2009;27:3290-6.

[29] Ricardi U, Filippi AR, Guarneri A, et al. Stereotactic body radiation therapy for early stage non-small cell lung cancer: results of a prospective trial. Lung Cancer 2010;68:72-7.

[30] Onishi H, Shirato H, Nagata Y, et al. Hypofractionated stereotactic radiotherapy (HypoFXSRT) for stage I non-small cell lung cancer: updated results of 257 patients in a Japanese multi-institutional study. J Thorac Oncol 2007;2:S94-S100.

[31] Grills IS, Mangona VS, Welsh R, et al. Outcomes after stereotactic lung radiotherapy or wedge resection for stage I non-small-cell lung cancer. J Clin Oncol 2010;28:928-35.

[32] Hurkmans CW, Cuijpers JP, Lagerwaard FJ, et al. Recommendations for implementing stereotactic radiotherapy in peripheral stage IA non-small cell lung cancer: report from the quality assurance working party of the randomised phase III ROSEL study. Radiat Oncol 2009;4.

[33] MacManus M, Nestle U, Rosenzweig KE, et al. Use of PET and PET/CT for radiation therapy planning: IAEA expert report 2006-2007. Radiother Oncol 2009;91:85-94.

[34] Crabtree TD, Denlinger CE, Meyers BF, et al. Stererotactic body radiation therapy versus surgical resection for stage I non small cell lung cancer. J Thorac Cardiovasc Surg 2010;140:377-86.

[35] De Ruysscher D, Wanders S, Minken A, et al. Effects of radiotherapy planning with a dedicated combined PET-CT-simulator of patients with non-small cell lung cancer on dose limiting normal tissues and radiation dose-escalation: a planning study. Radiother Oncol 2005;77:5-10.

[36] Dawood O. M. D. Anderson Cancer Center to Lead Study of Surgery vs. CyberKnife Radiosurgery for Operable Lung Cancer Patients. <http:// www.accuray.com/PressReleases.aspx?release $=676>$.

[37] Grutters JPC, Pijls-Johannesma M, Ruysscher DD, et al. The cost-effectiveness of particle therapy in non-small cell lung cancer: exploring decision uncertainty and areas for future research. Cancer Treat Rev, in press. doi: 10.1016/j.ctrv.2010.02.018. 